\title{
EXAMINING THE EFFECT OF TRAINING STRATEGIES ON EMPLOYEES' PERFORMANCE IN THE LIBYAN CONSTRUCTION INDUSTRY
}

\author{
Abdelnaser OMRAN \\ University Utara Malaysia, School of Economics, Finance and Banking, College of Business, 06010 Sintok, Kedah \\ State, Malaysia \\ E-mail: naser_elamroni@yahoo.co.uk
}

Paper received: 16.08.2016.; Paper accepted: 16.11.2016.

\begin{abstract}
Training is described as a structured intervention that is aimed at enhancing and improving key elements vital in individual performance. In other words, training and development consist of set of strategies, policies, lessons, tools and procedures designed to enhance the members or the employees at the organization. This study examined the effect of training strategies on the employees' performance in the Libyan construction companies. The population of this study consisted of the employees who worked in the construction companies in the eastern and central parts of Libya. A substantial literature review was done to obtain the information on training strategies and the development of human resources. A total of 400 designed structured questionnaires were distributed randomly to employees such as managers, heads of departments, technicians and workers in the selected companies. Of these, 243 questionnaires were duly completed and returned, yielding a response rate of $60.8 \%$. As results, it was found that the perception level towards training strategies was high (mean=3.34, $\mathrm{sd}=0.62)$. The results showed that there were significant relationships between all dimensions of training strategies and objective achievement. Training from the point of view of the trainers was found to have strong relationship with objective achievement $(r=0.620, p<0.01)$, followed by administrative and supervisory services $(r=0.589, p<0.01)$, curricula of training program $(r=0.529, p<0.01)$ and trainers $(r=0.418, p<0.01)$. There were also significant relationships between motivation and desire to change with training objective achievement.
\end{abstract}

Keywords: Training, Strategies, Performance, Employees, Construction companies, Libya.

\section{INTRODUCTION}

Performance management is a process by which managers and employees work together to plan, monitor and review an employee's work objectives and overall contribution to the organization. Many training programmes fail to acknowledge that while it is essential that managers deal with the effects of poor performance, they should also be devoting significant amounts of time and resources to helping the good performers in their teams to "raise their game" to new heights. Managers invariably find themselves spending the bulk of their time dealing with the performance of their weakest team members. This is usually at expense of investing more time with the strongest team members, who are often responsible for the bulk of performance success. One of the most difficult jobs for a manager is dealing with poor employee performance. For some managers, this is the most hated aspect of their job. However, wherever poor work performance is not properly diagnosed and confronted, the costs are great in lost productivity, rising customer complaints and lost profits. Recent reports from the government stated that employees' performance in the Libyan construction industry is suffering from many barriers which contributed to low performance of the employees at their construction companies and even made them to quit their current jobs and look for better careers due the low performance conducting by the human resources. Performance 
appraisal is an important human resource practice (Kuvaas, 2006). It was noticed that employees in Libyan construction companies were unsatisfied with their current job due to a lack of recognition and reward. This reason can be reflected in the fact that recognition helps in retaining the sincere employee and saves time and money to recruit new people. It also encourages other workers to do a good job. It is in fact quite difficult to believe, but it was observed that motivation could only be achieved if recognition was made. Previous study by Hansen et al. (Hansen et al.,2002) made a difference between recognition and reward, where he noted that 'intrinsic motivation is driven by the particular behaviour of extrinsic motivation and strategic recognition needed by an organization while implementing the reward strategy. It has also been observed a lack of communication as the main barrier for employees' motivation in the construction industry and this matter affected the intention of employees to stay with their organization (Salleh, 2013; Ali, 2013). Based on that it can simply be emphasized that inadequate communication between management and employees, and between departments, is the prime reason a worker quits an organization (Ali, 2013). The intention of this paper is to identify the main impact of training strategies on the employees' performance in order to develop human resources in the Libyan construction companies due to its crucial role.

\section{LITERATURE REVIEW}

Nowadays organizations and companies tend to use human resources management policies that are clearly based on their beliefs and principles to form a relationship between management and the employees of the organization, or they simply come up with policies that manage and contend with the current problem or requirement (Chew, 2005). In some previous studies, there have been identified six important human resource management practices crucial to organizations in becoming more efficient and effective. There practices namely are, recruitment, selection, compensation, employee participation, training and performance appraisal (Pfeffer, 1994; Delery and Doty, 1996). Similarly, a study by Sheppeck and Militello (Sheppeck and Militello 2000) classified human resource management into four groups employment skills and work policies, supportive environment, performance measurement and reinforcement and market organization which Guest (Guest ,1997) categorized into three groups: differentiated on innovation, focus on quality and cost-reduction. Moreover, Zaini et al. (Zaini et al., 2009) stated that human resource management practices of training and development, teamwork, human resource planning and performance appraisal have positive and significant relationship with organizations performance. Likewise, Lee and Lee (Likewise, Lee and Lee ,2007) argued that human resource management practices of training and development, teamwork, compensation, human resource planning, performance appraisal and employee security insures the organization`s performance such as employee`s productivity, product quality and firm's flexibility. The importance of human resource management practices such as recruitment and selection and employee monitoring in any given organization is obvious while a turnover of employees is a result of dissatisfaction with their jobs or apparently the availability of another job. This section presents a review on the employee performance, training and development:

\section{Employee Performance}

Armstrong (Armstrong, 2004) defined performance management as a means of getting better results from the whole organization by understanding and managing within an agreed framework, performance of planned goals, standards and competence requirements. The concepts of performance are studied through evaluation of overall performance and the management of the performance and the evaluation of performance represent the process classifying certain outcomes within a definite timeframe (Coens and Jenkins, 2002). It is important that all employees do their work properly and only in this way an organization can be successful. Fletcher (Fletcher, 1996) suggested that the main building blocks of a performance management system approach include: development of the organization's mission and objectives; enhancing communication within the organization so that employees are not only aware of the objectives and the business plan, but can contribute to their formulation; clarifying individual responsibilities and accountabilities; defining and measuring individual performance; implementing appropriate reward strategies, and developing staff to improve performance, and their career progression further in the future. Performance is a multidimensional concept and the companies need to be aware of its effects on their strategies and goals. Thus, employee performance carries huge importance 
and it's simply the heartbeat of the organization. According to Huselid (Huselid, 1995), employees within firms contribute to organizational performance and HRM practices can affect individual employee performance through their influence over employees' skills and motivation and through organizational structures that allow employees to improve the performance of their job. Also, he used labor turnover and productivity as employee performance measurements when he tests the influence of HRM practices on employee performance. Labor turnover is the rate at which an employer gains and loses employees. Organizations have learned the importance of employees and their work and they are aware that without them there is no chance that they will achieve their targeted goals (Mwita, 2000). Employee performance can be defined as the level and quality of effort, cooperation, commitment, lateness or absence as well as compliance with standard shown by an individual (Cronje et al., 1995). According to Huselid (Huselid, 1995), employees within firms contribute to organizational performance and HRM practices can affect individual employee performance through their influence over employees' skills and motivation and through organizational structures that allow employees to improve the performance of their jobs. Also, he used labor turnover, productivity as employee performance measurement when he tested the influence of HRM practices on employee performance. Employee performance can be described as employee effort to do their best to achieve their specific work goals which results in good outcome and behaviour (Ivancevich and Matteson, 1996). According to McConnell (McConnell, 2003) employee performance seen as achievement and contribution of an individual is practical and quantifiable. Moreover, employee performance is a complex concept which can be affected by many variables (Popovich, 1998). For instance, some variables like age, gender, employee recognition can contribute to job satisfaction (Fort and Voltero, 2004; Wright and Bonett, 2002; Cronin and Becherer, 1999). A study by Arnold and Feldman (Arnold and Feldman ,1982) concluded that perceptions of job security, the presence of a union, compensation level, job satisfaction, organizational tenure, demographic variables such as age, gender, education, and the number of dependents, organizational commitment, individual's expectations of employees, and the expressed intention to search for another job were all predictive of employee's leaving, and Sheridan
(Sheridan, 1992) also concluded that perceptions of organizational culture influenced a turnover. Managing employee performance can be done by assessing the individual's performance and giving rewards based on their outcomes. Thus, employee performance can be a result of one's ability and motivation. Green et al. (Green et al.,2006) reported that organizations that vertically aligned and horizontally integrated HR function and practices performed better and produced more. In other words, HR function is satisfied when employees exhibited improved individual and organizational performance. Tessember and Soeters (Tessember and Soeters, 2006) examined how, when and to what extent HR practices affect performance in Eritrea, Africa's youngest and poorest country. They reported that successful implementation of HR practices could enhance individual and civil service organization of Eritrea, but the economic and political environment within which HR practices operate are not conducive. There are other factors that determine the performance of employees such as, individual's capacity, willingness and the opportunity to perform. Additionally, performance based system can be an important tool for motivating employees so that they know that only their performance level will decide the compensation and bonuses they expect to receive (Ivancevich and Matteson, 1996). According to Den Hartog, Boselie and Paauwe (Hartog, Boselie and Paauwe, 2004), organization need to do implementation and realization of their strategies so that they can ensure employees to perform well and eventually maximize the organizational performance. Employee performance can be measured through absence, behaviour, turnover, and their reaction to work, such as staying or quitting the job. This performance can lead to quality outcomes as well as achieving the goals of the organization (Ali, 2000).

\section{Training and Development and Employee performance}

Training is described as a structured intervention that is aimed at enhancing and improving key elements vital in individual performance. In other words, training and development consist of a set of strategies, policies, lessons, tools and procedures designed to enhance the members or the employees in the organization (Delery and Doty, 1996). Management of an organization design and then carry out a training program that is believed to be crucial in improving the skills, performance and 
productivity of the employee in order to achieve the overall goals of the organization. Furthermore, training is an important human resource practice which is seen to be vital factor in any organization that aims to be productive and it is argued that higher productivity comes with providing a good training program in a firm (Aw and Tan, 1995). In many cases, many trained employees have moved to other companies, which became costly to organizations that already spent a lot and will have to find replacement for the vacancies left by former employees, so this has resulted in an increased cost to the firm. For this reason, they keep their current trained employees rather than lose them and replace by new ones who will need another training programs (Schaffner, 2001). Training programs can be a systematic process which identify what the employee needs, set annual training plans, explain the objectives of the training, decide the most appropriate methods of delivery, implement the training program, evaluate the outcome of the training and finally document the training records. Training programs that organizations implement to improve the skills of their newly recruits can come in many ways such as formal training program or informal training program which can be done on-the job or off-thejob (Saks, 1996). It is obvious that in most cases new recruits deal with anxiety and frustrations during their early period in an organization which comes with the unfamiliarity with the organization itself, the feeling of being short of skills needed to do certain tasks, so training program is one way of making sure that employees overcome such worries and tensions. Shiban (Shiban, 1990) tried to find out a methodology to determine the training needs of the system of government of the Sultanate of Oman. The study included the number of results, except the one that it did not consider. The training needs of all government entities are real, as confirmed by $37.2 \%$ of examinees. The training needs reflect $(55.6 \%)$ of the current requirements of government agencies only and $(32.5 \%)$ of the present and future needs. Abdulwahab (Abdulwahab, 1981) aimed to identify the training needs of a number of employees who work in government institutions in the Kingdom of Saudi Arabia. He wanted this study to emphasize the importance of training in the following topics which were the function of planning and to identify goals and objectives, delegation of powers, human relations, the oversight function, and development of Training Policy. Hence, if such employees decide to stay and stick with their organization, it's very likely that their performance and productivity will eventually drop (Kanelopoulos and Akrivos, 2006). As a result, the more the employees feel like they can't perform to the expectations of the organization, the higher the chances that their performances will slump. Tzafrir (Tzafrir, 2006) argued that training and development is the most common practice of human resource management practices. Moreover, training and development can play a key role in improving the knowledge, skills and abilities of the current employees for their future performances (Aswathappa, 2008). Similarly, Thang and Buyens (Thang and Buyens, 2008) illustrated that the training and development programs in an organization will directly result in a superior knowledge, ability and behaviour of employees which in time will improve financial and nonfinancial performance of the organization as well as the employee's performance. Organizations focus on making profits which is managed by cutting costs. Thus, improvements in employee's performance level is seen as return on investments of providing training and development sessions as such programs have carried costs to the company (Pfeffer, 1998). Therefore, during the implementation of the systematic training programs, organizations emphasize to their employees that they are worthy to the company (Subramaniam et al., 2011). Likewise, Islam and Siengthai (Likewise, Islam and Siengthai, 2010) indicated that organizations need to ensure that their training programs are matched and based on the labour demand features, workforce skill level, firm size as well as labour flexibility in various directions. One of the ways of improving employee's performance is training and development, it enhances their skills, knowledge and attitude towards the organization. Metaanalysis showed evidences that training programs can enhance employee performance level (Arthur et al., 2003). Tsai et al. (Tsai et al., 2007) suggested that if the employees are committed to learning during their training program, it is likely that they will have higher job satisfaction later which in return will have positive impact on their performance level. Therefore, it is safe to say that, employees who know and understand the benefits they gain from their training program will be satisfied compared to those who didn't attend any training programs or they attended training with no values gained.

\section{THE STUDY AREA}

Libya is an African country that spans over 1,759,540 square kilometers (679,182 Sq Miles), 
making it the $16^{\text {th }}$ largest nation in the world by size. It is linked to the North by the Mediterranean Sea, and bordered in the west by Tunisia and Algeria, in the Southwest by Niger, in the south by Chad and Sudan, and in the East by Egypt. Libya has the longest coast, which stretches by 1,770 kilometers (1,100 Miles) among all African countries bordering the Mediterranean. The portion of the Mediterranean Sea in the North of Libya is often referred to as the Libyan Sea. The construction industry in Libya is a consequence of the interaction among geographical, historical, social, organization, economic, and environmental factors. The Libyan industry operates in difficult geographical, social, economic circumstances.

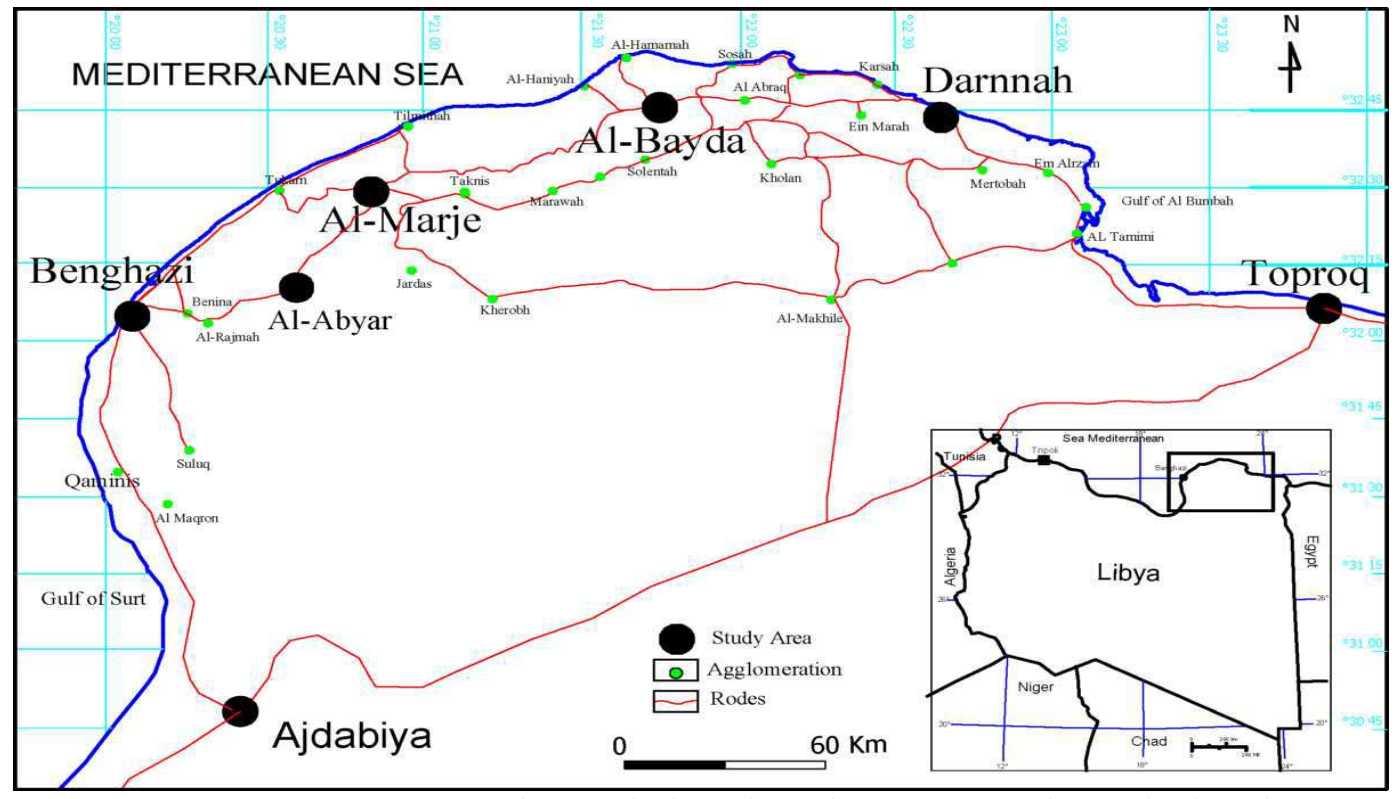

Figure 1: Map of Libya with the selected cities for study in Black Colour

\section{RESEARCH METHOD}

This research is focused on examining the effect of training strategies on the employees' performance in order to develop human resources in the Libyan construction companies. In order to test the proposed relationship between the independent variable (employees' performance) and dependent variable (training strategy and human resources development) in the construction companies in the central and eastern parts, the following hypotheses were proposed:

H1: There is a significant relationship between training strategy and employees' performance in the Libyan Construction companies.

H2: There is a significant relationship between developed human resources and employees' performance in the Libyan Construction companies.

The proposed framework in this study was adopted from Al-Faqiueh (Al-Faqiueh, 2014) who conducted a study on the impact of training strategies on the Performance of trainees in the National Water Company in the Kingdom of Saudi Arabia. The data was collected using the questionnaire survey method. In this study the target population was the company employees in the construction companies in the central and eastern parts of Libya. They were selected as a sampling frame. A sample of 234 respondents was randomly selected from about 400 construction companies, yielding a response rate of $60.8 \%$. The respondents were asked to rate the extent of each variable in the questionnaire that can examine the impact of training strategies on the employees' performance in order to develop human resources in the Libyan construction companies using a fivepoint Likert scale, which ranged from 1 (not important at all) to 5 (very important). The data collected was processed by using Statistical Package for Social Science (SPSS) program for Windows (Version 19.0).

\section{RESULTS ANALYSIS AND FINDINGS}

\section{Background of the Respondents}

This study consists of 234 respondents. Table 1 shows the characteristic of the 234 respondents involved in this study. 89.3 percent of them were male and only 10.7 percent were female. They 
were aged below 30 years $(21.0 \%), 30$ to 40 years (47.3\%), 41 to 50 years $(23.0 \%)$ and more than 50 years $(8.6 \%)$. Majority of them at least completed their Bachelor Degree (47.3\%) or Diploma (27.6\%). The respondents selected were among officers $(54.3 \%)$, Technicians $(17.3 \%)$, General Managers (1.2\%), Directors of Management $(11.1 \%)$, and head of departments $(16.0 \%)$. They have about adequate working experience, namely less than 5 years $(23.0 \%), 5$ to 10 years $(21.8 \%)$, 10 to 15 years $(31.3 \%)$ and more than 15 years $(23.9 \%)$.

Table 1: Background of the respondents

\begin{tabular}{|c|c|c|}
\hline & Frequency & Percentage \\
\hline \multicolumn{3}{|l|}{ Gender } \\
\hline Male & 217 & 89.3 \\
\hline Female & 26 & 10.7 \\
\hline \multicolumn{3}{|l|}{ Age } \\
\hline less than 30 years & 51 & 21 \\
\hline $30-40$ years & 115 & 47.3 \\
\hline $41-50$ years & 56 & 23 \\
\hline 50 years and above & 21 & 8.6 \\
\hline \multicolumn{3}{|l|}{ Educational Level } \\
\hline Secondary and below & 30 & 12.3 \\
\hline Diploma & 67 & 27.6 \\
\hline $\mathrm{BSc}$ & 115 & 47.3 \\
\hline MSc & 28 & 11.5 \\
\hline $\mathrm{PhD}$ & 3 & 1.2 \\
\hline \multicolumn{3}{|l|}{ Position } \\
\hline Officer & 132 & 54.3 \\
\hline Technician & 42 & 17.3 \\
\hline General Manager & 3 & 1.2 \\
\hline Director Management & 27 & 11.1 \\
\hline Head of Department & 39 & 16 \\
\hline \multicolumn{3}{|l|}{ Working Experiences } \\
\hline Less than 5 years & 56 & 23 \\
\hline $5-10$ years & 53 & 21.8 \\
\hline $10-15$ years & 76 & 31.3 \\
\hline More than 15 years & 58 & 23.9 \\
\hline
\end{tabular}

\section{Frequency of Training at the Construction Companies}

The respondents were asked about the frequency of training provided by the companies. Several options were provided to the respondents to indicate their choices. However, as presented in Table 2, it can be observed that almost sixty-seven percent $(66.7 \%)$ of the participants indicated that there was not any training offered at their companies. But, it was realized that other companies used to offer training programs for their employees once a year $(14.8 \%)$ while other companies used to organize just one training at the $\operatorname{start}(9.1 \%)$.
Table 2: Training programs offered at the construction companies

\begin{tabular}{|l|c|}
\hline \multicolumn{1}{|c|}{ Options } & Frequency (\%) \\
\hline $\begin{array}{l}\text { Just once in the beginning when } \\
\text { work started }\end{array}$ & $22(9.1 \%)$ \\
\hline Once a year & $36(14.8 \%)$ \\
\hline Twice a year & $11(4.5 \%)$ \\
\hline Once a month & $12(4.9 \%)$ \\
\hline There was no training at all & $162(66.7 \%)$ \\
\hline \multicolumn{1}{|c|}{ Total } & $\mathbf{2 4 3 ( 1 0 0 )}$ \\
\hline
\end{tabular}

\section{The Trainers}

This question aims to look for persons who are responsible for the trainings held in the construction companies in Libya, either the trainers hired from the company, or teachers sourced from outside agencies. However, $12.3 \%$ of the respondents mentioned that the trainers were the supervisors from the company they work for followed by other $11.1 \%$ who mentioned that the trainers were lecturers hired from outside but at the same time it was surprising to see that almost sixty-seven $(66.7 \%)$ did confirm that nobody trained them so far (Refer to Table 3).

Table 3: Frequency of the training programs offered at the construction companies

\begin{tabular}{|c|c|}
\hline Option & Frequency $(\%)$ \\
\hline Trainers & $12(4.9 \%)$ \\
\hline Lecturer hired from outside & $27(11.1 \%)$ \\
\hline Manager & $4(1.6 \%)$ \\
\hline Supervisor & $30(12.3 \%)$ \\
\hline Trainers and supervisor & $7(2.9 \%)$ \\
\hline Other & $1(0.4 \%)$ \\
\hline No body trained us at all & $162(66.7 \%)$ \\
\hline Total & $243(100 \%)$ \\
\hline
\end{tabular}

\section{Validity Analysis (Factor Analysis)}

\section{Training Strategy}

The original measurement scales for training strategies consisted of 40-items. Three items were suggested to be deleted, making 37 items left for the analysis. The Varimax rotated principal components factor analysis was conducted. Prior to performing the principal components analysis (PCA), the suitability of the data for factor analysis was assessed. Correlation matrix indicated item coefficients were 0.3 and above. There were a total of two statistical measures to assess the factorability of the data conducted through 1) Kaiser-Meyer-Olkin (KMO) to determine the "measure of sampling adequacy" value. The value 
reported was 0.900 , exceeding the recommended value of $0.6 ; 2$ ) Barlett's test of sphericity (Barlett, $1954)$ is significant at $p<0.001$. Since, the KMO value is reported as 0.900 , it is interpreted as in the range of "great" (Hutchinson and Sofroniou, 1999). Therefore, the sample size was adequate for factor analysis. The total variance explained is reported as $58.06 \%$. Only factors with a loading value of 0.45 and above were considered. Factor loading accepted all five factors based on original items. Table 4 below shows the factor loading value for this scale.

\section{Development of Human Resource}

Therefore, the sample size is adequate for factor analysis. Factor loading also accepted two (2) factors based on the original instrument. The total variance explained is reported as $67.99 \%$. Only factors with a loading value of 0.40 and above were considered. Therefore, 1 item was deleted. Table 5 below shows the factor loading value for this scale.

Table 4: Factor loading of training strategies

\begin{tabular}{|c|c|c|c|c|c|}
\hline \multirow{2}{*}{ Factor/Dimension } & \multicolumn{5}{|c|}{ Factor Loading } \\
\hline & 1 & 2 & 3 & 4 & 5 \\
\hline \multicolumn{6}{|l|}{ Factor 1: Administrative and Advisory Services } \\
\hline \begin{tabular}{|l} 
The company considers training as its main strategic \\
priority
\end{tabular} & 0.729 & & & & \\
\hline $\begin{array}{l}\text { The company seeks continuous improvement by } \\
\text { implementing methods of work that lead to success }\end{array}$ & 0.745 & & & & \\
\hline $\begin{array}{l}\text { The company provides financial resources and facilities } \\
\text { necessary to support training }\end{array}$ & 0.761 & & & & \\
\hline $\begin{array}{l}\text { There are open channels of communication between senior } \\
\text { management and trainers }\end{array}$ & 0.673 & & & & \\
\hline $\begin{array}{l}\text { The company works to create a positive environment and to } \\
\text { encourage training, such as providing transportation and } \\
\text { housing }\end{array}$ & 0.651 & & & & \\
\hline $\begin{array}{l}\text { There is sufficient financial means and materials available } \\
\text { to provide appropriate training programs }\end{array}$ & 0.713 & & & & \\
\hline $\begin{array}{l}\text { Clarity of strategies, objectives and policies of the company } \\
\text { is evident }\end{array}$ & 0.729 & & & & \\
\hline $\begin{array}{l}\text { There is a belief in the positive consequences of training and } \\
\text { in raising the efficiency of employees among senior } \\
\text { management }\end{array}$ & 0.704 & & & & \\
\hline \multicolumn{6}{|l|}{ Factor 2: Trainers } \\
\hline $\begin{array}{l}\text { Qualified trainers are selected for the implementation of } \\
\text { training programs }\end{array}$ & & 0.538 & & & \\
\hline $\begin{array}{l}\text { Trainers from within the company have more understanding } \\
\text { of the training needs than external trainers }\end{array}$ & & 0.552 & & & \\
\hline $\begin{array}{l}\text { Providing trainers from outside the company increases the } \\
\text { expertise of trainees }\end{array}$ & & 0.698 & & & \\
\hline $\begin{array}{l}\text { The experience of trainers affect changing the trends of the } \\
\text { trainees behaviour toward a better performance }\end{array}$ & & 0.694 & & & \\
\hline $\begin{array}{l}\text { Education qualification for trainers' aids in delivering the } \\
\text { objectives of the training more clearly and accurately }\end{array}$ & & 0.612 & & & \\
\hline $\begin{array}{l}\text { The company trainers are capable in utilizing modern } \\
\text { training techniques efficiently }\end{array}$ & & 0.496 & & & \\
\hline $\begin{array}{l}\text { Qualified trainers who possess the appropriate academic } \\
\text { qualifications to cover training courses are selected }\end{array}$ & & 0.538 & & & \\
\hline
\end{tabular}




\section{Table 4: Factor loading of training strategies (continued)}

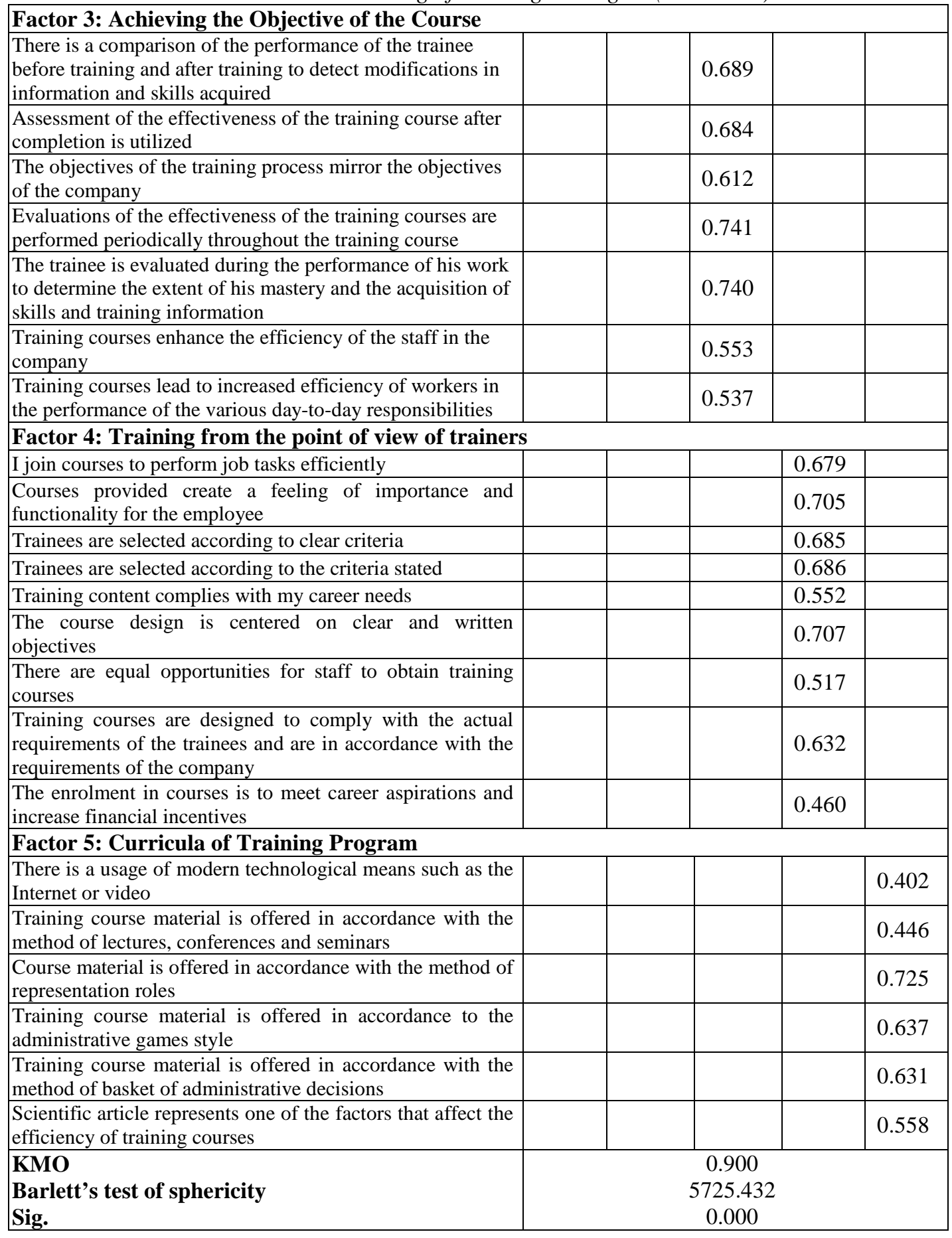

\section{Descriptive Analysis}

Descriptive analysis was used to examine the perception level of the variables. To determine the perception level of these variables, the researcher computed the mean and used the middle point to separate the low, moderate and high level as mentioned by Healey (2005). Mean score is divided in three levels; low (mean $=1.00$ to 2.66), moderate (mean $=2.67$ to 3.33) and high (mean=3.34 to 5.00). The results of descriptive analysis are summarized in Table 6. Descriptive analysis which examined the perception level on training strategies and development of Human Resource is shown in Table 6. Perception level towards training strategies was high (mean $=3.34$, $\mathrm{sd}=0.62$ ). Respondents also score the higher mean for trainers (mean=3.60, $s d=0.71)$, and the training from the point of view of trainers (mean=3.39, $\mathrm{sd}=0.79$ ). However, they score the moderate level of perception for curricula of the training program (mean=3.27, $\quad \mathrm{sd}=0.70$ ), administrative and 
supervisory services (mean $=3.25, \mathrm{sd}=1.00$ ) and achieving the objective of the program (mean=3.20, sd=0.88). It was also found that the respondents perceive the higher agreement towards development of human resource (mean $=3.92$, $\mathrm{sd}=0.80$ ). They also score the high mean for both dimensions in development of human resource, that were motivation (mean $=3.93, \mathrm{sd}=0.86$ ) and desire to change $($ mean $=3.91, \mathrm{sd}=0.84)$.

\section{Table 5: Factor Loading of Development of Human Resource}

\begin{tabular}{|c|c|c|}
\hline \multirow{2}{*}{ Factor/Dimension } & \multicolumn{2}{|c|}{ Factor Loading } \\
\hline & 1 & 2 \\
\hline \multicolumn{3}{|l|}{ Factor 1: Motivation } \\
\hline Training increases the skills of staff and their overall ability to make decisions & 0.811 & \\
\hline Training increases the ability to accomplish various daily transactions more quickly & 0.803 & \\
\hline Training increases the efficiency in dealing with the recipients of the company's services & 0.794 & \\
\hline Training courses raise employee morale and self-confident & 0.770 & \\
\hline Training works to raise the capacity of the staff when dealing with superiors & 0.762 & \\
\hline Training is aiding in the development of my functional abilities & 0.760 & \\
\hline Training improves ones behaviours and helps to aid in cooperating with others & 0.734 & \\
\hline Training raises the level of general knowledge and skills of the staff & 0.731 & \\
\hline Training increases the ability to compete in the use of modern technologies & 0.721 & \\
\hline \multicolumn{3}{|l|}{ Factor 2: Desire for Change } \\
\hline Training provides alternative views of a process that can also be applied to improve the work & & 0.781 \\
\hline Training provides the ability to change methods to improve daily tasks & & 0.756 \\
\hline Training leads to the invention of new ways of completing tasks & & 0.750 \\
\hline Training should be in accordance with modern techniques & & 0.744 \\
\hline Training has a positive effect on the ability to keep up with rapid changes in the workplace & & 0.731 \\
\hline Training aids in the understanding organizational culture among staff & & 0.728 \\
\hline Training enables staff to use scientific methods in the implementation of the tasks delegated & & 0.686 \\
\hline Training is necessary for the institution's desire for a change in policies implemented & & 0.666 \\
\hline Future career choices may require distinct skills and abilities & & 0.626 \\
\hline Training helps to identify and modify unacceptable behaviours & & 0.624 \\
\hline KMO & 0.943 & \\
\hline Barlett's test of sphericity & 4182.900 & \\
\hline Sig. & 0.000 & \\
\hline
\end{tabular}

Table 6: Descriptive Analysis of the Variables

\begin{tabular}{|l|c|c|}
\hline Dimensions/Variable & Mean & $\begin{array}{c}\text { Standard } \\
\text { Deviation }\end{array}$ \\
\hline Training Strategies & $\mathbf{3 . 3 4}$ & $\mathbf{0 . 6 2}$ \\
\hline Trainers & 3.60 & 0.71 \\
\hline Curricula of Training Program & 3.27 & 0.70 \\
\hline $\begin{array}{l}\text { Training from the point of } \\
\text { view of Trainers }\end{array}$ & 3.39 & 0.79 \\
\hline $\begin{array}{l}\text { Administrative and Supervisory } \\
\text { Services }\end{array}$ & 3.25 & 1.00 \\
\hline $\begin{array}{l}\text { Achieving the Objective of the } \\
\text { Course }\end{array}$ & 3.20 & 0.88 \\
\hline $\begin{array}{l}\text { Development of Human } \\
\text { Resource }\end{array}$ & $\mathbf{3 . 9 2}$ & $\mathbf{0 . 8 0}$ \\
\hline Motivation & 3.93 & 0.86 \\
\hline Desire to Change & 3.91 & 0.84 \\
\hline
\end{tabular}

\section{Regression Analysis}

In this study, regression analysis was conducted to examine the effect of the demographic background, training strategies and human resource Development on the training objective achievement.

\section{Demographic Background}

Table 7 exhibits the results of regression analysis to examine the effect of demographic variables on training objective achievement. It was found that demographic variables did not have the significant effect on training objective achievement $\left(\mathrm{R}^{2}=0.038, \mathrm{~F}=0.766, \mathrm{p}>0.05\right)$. All of the variables also failed to predict the achievement of the objective of the training program.

\section{Training Strategies}

Table 8 shows the results of regression analysis to examine the effect of training strategies on the objective achievement of training program. It was revealed that training strategies explained 46.0 percent of the objective achievement of training program $\left(\mathrm{R}^{2}=0.460, \mathrm{~F}=50.730, \mathrm{p}<0.01\right)$. Out of 
four dimensions, only three of them were successfully predicted objective achievements of the training program. There were curricula of the training program $(\mathrm{B}=0.260, \mathrm{t}=3.127, \mathrm{p}<0.01)$, training from the point of view of trainers $(\mathrm{B}=0.382, \mathrm{t}=4.622, \mathrm{p}<0.01)$ and administrative and supervisory services $(\mathrm{B}=0.236, \mathrm{t}=4.016, \mathrm{p}<0.01)$.

Table 7: Effect of demographic background on training objective achievement

\begin{tabular}{|l|c|c|c|}
\hline \multicolumn{1}{|c|}{$\begin{array}{c}\text { Demographic } \\
\text { Background }\end{array}$} & $\mathbf{B}$ & $\mathbf{t}$ & Sig. \\
\hline Gender & -0.184 & -0.976 & 0.330 \\
\hline $\begin{array}{l}\text { Less than 30 years } \\
\text { old }\end{array}$ & 0.054 & 0.343 & 0.732 \\
\hline 41 to 50 years old & 0.009 & 0.061 & 0.951 \\
\hline $\begin{array}{l}\text { More than 50 years } \\
\text { old }\end{array}$ & 0.361 & 1.630 & 0.104 \\
\hline Secondary & 0.155 & 0.806 & 0.421 \\
\hline Diploma & 0.007 & 0.049 & 0.961 \\
\hline Masters & -0.076 & -0.394 & 0.694 \\
\hline PhD & 0.130 & 0.240 & 0.810 \\
\hline Technician & 0.098 & 0.609 & 0.543 \\
\hline General Manager & 0.466 & 0.869 & 0.386 \\
\hline $\begin{array}{l}\text { Director } \\
\text { Management }\end{array}$ & 0.106 & 0.526 & 0.599 \\
\hline Head of Department & -0.145 & -0.856 & 0.393 \\
\hline $\mathrm{R}^{2}$ & \multicolumn{3}{|c|}{0.038} \\
\hline F & \multicolumn{3}{|c|}{0.666} \\
\hline Sig. & \multicolumn{3}{|l}{} \\
\hline
\end{tabular}

Table 8: Effect of training strategies on training objective achievement

\begin{tabular}{|l|c|c|c|}
\hline \multicolumn{1}{|c|}{ Training Strategies } & B & $\mathbf{t}$ & Sig. \\
\hline Trainers & -0.049 & -0.609 & 0.543 \\
\hline $\begin{array}{l}\text { Curricula of Training } \\
\text { Program }\end{array}$ & 0.260 & 3.127 & 0.002 \\
\hline $\begin{array}{l}\text { Training from the point } \\
\text { of view of Trainers }\end{array}$ & 0.382 & 4.622 & 0.000 \\
\hline $\begin{array}{l}\text { Administrative and } \\
\text { Supervisory Services }\end{array}$ & 0.236 & 4.016 & 0.000 \\
\hline $\mathrm{R}^{2}$ & \multicolumn{3}{|c|}{0.460} \\
\hline F & \multicolumn{3}{|c|}{50.730} \\
\hline Sig. & \multicolumn{3}{|c|}{0.000} \\
\hline
\end{tabular}

\section{Development of Human Resource}

The effect of the development of Human Resource on the achievement of training objective was examined. As it is shown in Table 9, it was found that the development of human resource has 26.5 percent effect on the achievement of training objectives $\quad(\mathrm{R} 2=0.265, \quad \mathrm{~F}=43.275, \quad \mathrm{p}<0.01)$. However, only one dimension, motivation, was significant $(B=0.575, t=6.261, \mathrm{p}<0.01)$.
Table 9: Effect of the development of human resource on training objective achievement

\begin{tabular}{|l|c|c|c|}
\hline $\begin{array}{c}\text { Development of } \\
\text { Human } \\
\text { resource }\end{array}$ & B & $\mathbf{t}$ & Sig. \\
\hline Motivation & 0.575 & 6.261 & 0.000 \\
\hline Desire to Change & -0.059 & -0.628 & 0.530 \\
\hline $\mathrm{R}^{2}$ & \multicolumn{3}{|c|}{0.265} \\
\hline $\mathrm{F}$ & \multicolumn{3}{|c|}{43.275} \\
\hline Sig. & \multicolumn{3}{|c|}{0.000} \\
\hline
\end{tabular}

\section{CONCLUSION}

This study examines the effect of training strategies on the employees' performance in order to develop human resources in the Libyan construction companies. It was found that most of the participants were not offered any training in their companies. This study reveals that the perception level towards training strategies was high and this study concluded that there was no significant relationship found between gender, age, education level, position and experience with achieving the objective of the training, but there were significant relationships between all dimensions of training strategies and human resource development with the training objective achievement. In addition to that, it can be concluded that the demographic variables did not have any significant effects on training objective achievement. It is obviously found that all of the variables also failed to predict the achievement of the objective of the training program. However, it can only be concluded that the effect of training strategies on the objective achievement of training program found out that out of four dimensions, only three of them successfully predicted the objective achievement of the training program. These four dimensions were found to be (i) curricula of the training program, (ii) training from the point of view of trainers, and (iii) administrative and supervisory services. The study also found that the effect of the development of human resource on the achievement of training objective was significant. It is obvious that training strategies and human resources development are useful and significant for an organization to improve managers, employees and organizational performance. In final word, it can be stated here that training strategies and human resource development cannot be disconnected from any business activities in organizations, firms or companies. 


\section{REFERENCES}

Abdulwahab, A. (1981). Training and Development: An Introduction to the scientific effectiveness of individuals and organizations. Riyadh: Institute of Public Administration

Al-Faqeih, O.S. (2014). Impact of Training Strategies on the Performance of Trainees in the National Water Company in the Kingdom of Saudi Arabia. Universiti Sains Malaysia, Malaysia.

Ali, M.A.A. (2013). Determining the relationship between Communication Dimensions and Organizational culture in the Libyan Construction Industry. Universiti Sains Malaysia, Malaysia.

Armstrong, M., and Baron, A. (2004). Managing Performance: Performance management in action, London: CIPD.

Arnold, H.J., \& Feldman, D.C. (1982) A multivariate analysis of the determinants of job turnover. Journal of Applied Psychology, 67, 350-360.

Arthur, W.J., \& Bennett, W.J. (2003). Effectiveness of Training in Organizations: A Meta - Analysis of Design and Evaluation Features. Journal of Applied Psychology, 88 (2): 234-245.

Aswathappa, K. (2006). Human resource and personnel management text and cases. Fourth edition, Tata McGraw-hill publishing company.

Aw, B., \& Tan, H. (1995). Training, Technology and Firm-Level Productivity in Taiwan. Paper presented at the Conference on Enterprise and Training Strategies and Productivity, World Bank,China.

Bartlett, M.S. (1954). A further note on the multiplying factors for various $\mathbf{X}^{2}$ approximations in factor analysis. Journal of the Royal Statistical Society, 16, 296-298.

Chew, Y. (2005). Achieving Organizational Prosperity through Employee Motivation and Retention: A Comparative Study of HRM Practices in Malaysian Institutions. Research and Practice in Human Resource Management, 13(2): 87-104.

Coens, T., \& Jenkins, M. (2000). Abolishing Performance Appraisals. San Francisco: BerrettKoehler Publishers, Inc.

Cronin, S.N., \& Becherer, D. (1999). Recognition of Staff Nurse Job Performance and Achievements: Staff and Manager Perceptions. Journal of Nursing Administration, 29(1): 26-31.

Cronje, G.J. de J., Hugo, W.M.J., Neuland, E.W. \& Van Reunen, M.J. (1995). Introduction to business management (3rd ed.). Halfway House: Southern Book Publishers.

Delery, J.E., \& Doty, D.H. (1996). Theoretical frameworks in strategic human resource management: Universalistic, contingency and configurational perspectives. Academy of Management Journal, 39, 802-835.

Fletcher, C., \& Williams, R. (1996). Performance management, Job satisfaction and Organizational commitment. The developing research agenda,
Journal of Occupational and Organizational Psychology, 7(2):169-179.

Fort, A.L., \& Voltero, L. (2004). Factors affecting the Performance of Maternal Health Care Providers in Armenia. Human Resources Health, 2(1), 8-12.

Green, W.K., Wu, C., Whitten, D., \& Medlin, B. (2006). The Impact of Strategic Human Resource Management on Firm Performance and Human Resource Professionals' Work Attitude and Work Performance. International Journal of Human Resource Management, 8(3): 263-276.

Guest, D.E. (1997). The nature and causes of effective human resource management: A review and research agenda. The International Journal of Human Resource Management, 8: 263- 276.

Hair, J., Celsi, M., Money, A., Samouel, P., \& Page, M. (2011). Essentials of Business Research Methods (1st edition), New York City: M.E. Sharpe.

Hansen, F., Smith, M., \& Hansen, R. (2002). Rewards and recognition in employee motivation. Compensation and Benefits Review (October), 6171.

Huselid, M.A. (1995). The impact of human resource management practices on turnover, productivity, and corporate financial performance. Academy of Management Journal, 38: 635-672.

Hutcheson, G.D., \& Sofroniou, N. (1999). The Multivariate Social Scientist. London: SAGE.

Islam, M.Z. and Siengthai, S. (2010) "Human Resource Management Practices and Firm Performance Improvement in Dhaka Export Processing Zone. Research and Practice in Human Resource Management, 18(1): 60-77.

Ivancevich, J.M. \& Matteson, M.T. (1996). Organizational Behavior and Management. Chicago: Irwin.

Kanelopoulos, C., \& Akrivos, C. (2006). "Career development in Greek management”, Spoudai, 56(1):79-106.

Kuvaas, B. (2006). Performance appraisal satisfaction and employee outcomes: Mediating and moderating roles of work motivation. The International Journal of Human Resource Management, 17(3): 504-522.

Lee, Y.C., \& Lee, S.K. (2007). Capability, processes, and performance of knowledge management: a structural approach. Human Factors and Ergonomics in Manufacturing, 17(1): 21-41.

McConnell, C.R. (2003). The Manger's Approach for Employee Performance Problems. Health Care Manager, 22(1): 63-69.

Mwita, J.I. (2000). Performance Management Model, a system-based approach to system quality. The International Journal of Public Sector Management, 13(1): 19-12.

Pfeffer, J. (1994). Competitive advantage through people. Harvard Business School Press, Boston: MA.

Pfeffer, J. (1998). Seven practices of successful organizations. California Management Review, 40(2): 96-124. 
Popovich, M.G. (1998). Creating High-Performance Government Organizations: A Practical Guide for Public Managers. New York: Jossey-Bass.

Saks, M.A. (1996). The Relationship between the Amount and Helpfulness of Entry Training and Work Outcomes. Human Relations, 49: 429- 451.

Salleh, M.S.H. (2013). Factors affecting construction productivity in the Libyan construction industry, Unpublished PhD Thesis, Universiti Sains Malaysia, Malaysia.

Sallum, H.S. (2002). Assessing the Performance of Trainers on Military Hardware. Unpublished MSc Thesis, Naif Arabic for Security Sciences, Riyadh.

Schaffner, J.A. (2001). Turnover and Job Training in Developing and Developed Countries: Evidence from Colombia and the United States. http://www.google.com [14/9/2015].

Sheppeck, M.A., \& Militello, J. (2000). Strategic HR configuration and organizational performance. Humam Resources Management, 9(1): 5-16.

Sheridan, J.E. (1992). Organizational culture and employee retention. Academy of Management Journal, 35, 1036-1056.

Shiban, U.A. (1990). Methodology to Determine the Training Needs of System of Government of the Sultanate of Oman, Administrative, 40: 175- 220.

Subramaniam, C., Shamsudin, F.M., \& Ibrahim, H. (2011). Linking human resource practices and organisational performance: Evidence from small and medium organizations in Malaysia. Jurnal Pengurusan, 32, 27-37.

Tessema, M.T., \& Soeters, J.L. (2006). Challenges and Prospects of HRM in Developing Countries: Testing the HRP-Performance Link in Eritrea Civil Service. International Journal of Human Resource Management, 17(1): 86-105.

Thang, N.N., \& Buyens, D. (2008), What We Know about Relationship between Training and Firm Performance: A Review of Literature. Paper Presented at The 7th International Conference on Ethics and Quality of Work-Life for Sustainable Development, Bangkok, Thailand.

Torrington, D., Hall, L., \& Stephen, T. (2008). Human Resource Management (7th ed.), Edinburg: Pearson, Education Limited.

Tsai, P., Yen, C.Y., Huang, L., \& Huang, I. (2007). A study on motivating employee's learning commitment in the post-downsizing era: job satisfaction perspective. Journal of World Business, 42(2), 157-169.

Tzafrir, S.S. (2006). A Universalistic Perspective for Explaining the Relationship between HRM Practices and Firm Performance at Different Points in Time. Journal of Managerial Psychology, 21 (2): 109-130.

Wright, T.A., \& Bonett, D.G. (2002). The Moderating Effects of Employee Tenure on the Relation between Organizational Commitment and Job Performance: A Meta-Analysis. Journal of Applied Psychology, 87(6): 1183-1190.

Zaini, A., Nilufar, A., \& Syed, S.A. (2009). The Effect of Human Resource Management Practices on Business Performance among Private Companies in Malaysia. International Journal of Business and Management, 4(6), 65-72.

\title{
ISPITIVANJE EFEKTA STRATEGIJE OBUKE NA UČINAK ZAPOSLENIH U LIBIJSKOM GRAĐEVINARSTVU
}

\begin{abstract}
Obuka je ovde opisana kao strukturirana intervencija, koja ima za cilj unapređenje i poboljšanje ključnih elemenata vitalnih za individualni učinak. Drugim rečima, obuka i razvoj sastoje se od niza strategija, politika, lekcija, alata i procedura, dizajniranih da unaprede članove ili zaposlene u organizaciji. Ova studija ispituje uticaj strategija obuke na rad zaposlenih u libijskim građevinskim firmama. Uzorak ove studije sastojao se od zaposlenih koji su radili u građevinskim firmama u istočnim i centralnim delovima Libije. Značajan pregled literature je urađen da se dobiju informacije o strategijama obuke i razvoju ljudskih resursa. Ukupno 400 dizajniranih strukturiranih upitnika su nasumično raspoređeni zaposlenima, kao što su menadžeri, šefovi odeljenja, tehničari i radnici u odabranim kompanijama. Od tog broja, 243 upitnika su uredno popunjeni i vraćeni, što je $\mathbf{6 0 , 8 \%}$. Kao rezultat, utvrđeno je da je nivo percepcije prema strategijama obuke bila visoka $(m e a n=3.34$, $s d=0.62$ ). Rezultati su pokazali da postoje značajne korelacije između svih dimenzija strategija obuke i objektivnih postognuća. Ustanovljeno je da obuka iz ugla trenera ima: snažne korelacije sa objektivnim postignućima $(r=0.620, p<0,01)$, zatim sa administrativnim i nadzornim uslugama $(r=0.589, p<0.01)$, nastavnim planovima $i$ programima obuke $(r=0.529, p<0,01)$ i samim trenerima $(r=0.418, p<0,01)$. Tu su takode značajne korelacije između motivacije i želje za promenom sa objektivnim postignućima treninga.
\end{abstract}

Ključne reči: Trening, Strategije, Performanse, Zaposleni, Građevinske kompanije, Libija. 